\title{
Career Adaptability Pada Kelompok Disabilitas Dan Non Disabilitas: Kajian Komparatif
}

\author{
Unita Werdi Rahajeng \\ Jurusan Psikologi Fakultas Ilmu Sosial dan Politik Universitas Brawijaya \\ unita@ub.ac.id \\ Alies Poetri Lintangsari \\ Program Studi Pendidikan Bahasa Inggris Fakultas Ilmu Sosial dan Politik \\ Universitas Brawijaya \\ alieslintang@ub.ac.id \\ Ari Pratiwi \\ Jurusan Psikologi Fakultas Ilmu Sosial dan Politik Universitas Brawijaya \\ ari.pratiwi@ub.ac.id
}

\begin{abstract}
Abstrak
Career adaptability memprediksikan kelenturan individu dalam menghadapi tuntutan kerja. Dalam era persaingan kerja yang bersifat dinamis, career adaptability dipandang sebagai modalitas yang dapat memprediksikan keberhasilan karir seseorang. Penelitian ini memusatkan pada perbandingan career adaptability pada kelompok disabilitas dan non disabilitas, yang pada era ini dihadapkan pada era persaingan pasar kerja yang inklusif. Dalam penelitian ini melibatkan 88 orang responden penyandang disabilitas dan 134 orang responden non disabilitas yang berdomisili di Jawa Timur. Responden mengisi survey secara online berupa skala Career Adapt-Abilities Scale (CAAS) yang telah diadaptasikan dalam konteks Indonesia. Dari hasil analisis menggunakan independent sample t-test didapatkan perbedaan yang signifikan antara career adaptability kelompok penyandang disabilitas dan non disabilitas $(t=3.138$, $p=0.002)$. Secara umum career adaptability penyandang disabilitas $(M=4,128$, $\mathrm{SD}=0,444)$ lebih tinggi daripada career adaptability non disabilitas $(\mathrm{M}=4,128$, $\mathrm{SD}=0,404)$. Hasil penelitian ini menepis anggapan negatif terkait modialitas penyandang disabilitas dalam memenuhi tantangan pasar kerja.
\end{abstract}

Kata kunci: career adaptability; employability; inklusif; tenaga kerja

\section{Pendahuluan}

Berdasarkan data dari ILO (2017) di Indonesia hanya terdapat 54,63\% penyandang disabilitas ringan dan $18,32 \%$ penyandang disabilitas berat yang terserap lapangan kerja. Angka ini masih terbilang rendah dibandingkan total $66,42 \%$ angkatan kerja non disabilitas yang terserap lapangan kerja. Ditambah lagi sebagian besar tenaga kerja disabilitas hanya terserap di sektor informal 
(75,8\% penyandang disabilitas berat dan $64,93 \%$ penyandang disabilitas ringan). Sedangkan sisanya dengan perbandingan yang lebih kecil terserap di sektor formal. Fakta yang berkebalikan dengan angkatan kerja non disabilitas yang terserap cukup seimbang pada sektor formal (50,73\%) dan sektor informal $(49,27 \%)$. Secara umum, penelitian-penelitian terdahulu menyatakan bahwa kondisi disabilitas memang menurunkan probabilitas untuk direkrut sebagai tenaga kerja (ILO, 2017; Jones, Mavromaras, Sloane, \& Wei, 2011). Menilik fakta tersebut, seakan masih ada kesenjangan yang besar antara serapan tenaga kerja disabilitas dan non disabilitas.

Pemerintah sendiri turut andil untuk mendorong peningkatan serapan tenaga kerja disabilitas di lapangan kerja. Undang-undang Republik Indonesia No 8 Tahun 2016 mengamanahkan pemenuhan kesetaraan hak penyandang disabilitas, salah satunya pada bidang pekerjaan. Penyandang disabilitas memiliki hak yang setara dengan populasi lainnya untuk terserap di berbagai lapangan pekerjaan dan mendapatkan aksesibilitas untuk bekerja. Pemerintah juga mewajibkan organisasi pemerintah serta sektor swasta memberikan porsi minimal bagi penyandang disabilitas (berkisar antara 1\%-2\%).

Adanya peraturan dan pengakuan kesetaraan hak bagi para penyandang disabilitas untuk memasuki pasar kerja akan mendorong persaingan kerja yang makin inklusif. Dalam persaingan kerja yang inklusif, para penyandang disabilitas diharapkan dapat menunjukkan performa kerja setara dengan non disabilitas dalam menjawab tantangan kerja masa kini dan masa mendatang. Penyandang disabilitas tidak dilihat sebagai pekerja kelas dua atau masuk ke lapangan kerja karena belas kasihan semata. Mempertimbangkan fakta serapan tenaga kerja yang telah dijelaskan sebelumnya, seakan-akan terdapat kesenjangan antara modalitas yang dimiliki oleh penyandang disabilitas dan non disabilitas sehingga profil pekerja penyandang disabilitas dianggap kurang menarik untuk diserap di lapangan pekerjaan. Sejalan dengan berbagai temuan sebelumnya memang masih banyak pengelola lapangan kerja yang meragukan kapasitas penyandang disabilitas untuk bekerja (Kaye, Jans, \& Jones, 2011). Oleh karena itu, peneliti 
tertarik untuk membuktikan apakah terdapat kesenjangan modalitas penyandang disabilitas dan non disabilitas dalam menghadapi pasar kerja.

Untuk menjawab pertanyaan penelitian tersebut, peneliti menggunakan kerangka career construction theory/CCT (Savickas, 2005). CCT memiliki konsep bahwa perkembangan manusia didorong oleh adaptasinya terhadap lingkungan sosial dengan integrasi individu-lingkungannya. Dunia kerja di abad 21 memiliki karakteristik yang berbeda dengan sebelumnya, yang ditandai dengan proses globalisasi dan perubahan cepat di bidang teknologi informasi. Prospek kerja saat ini lebih sulit untuk diprediksikan, dengan transisi pekerjaan yang lebih sering dan sulit. Perbedaan karakteristik tersebut menuntut para pekerja untuk mengembangkan ketrampilan serta kompetensi yang memiliki perbedaan substansial dengan tuntutan di masa-masa sebelumnya. Idealnya pekerja memiliki karakter pembelajar berkelanjutan (lifelong learner) untuk menguasai teknologi terkini, mengedepankan fleksibilitas dibandingkan mengutamakan stabilitas, dan aktif menciptakan kesempatan kerja bagi dirinya (Savickas, dkk, 2009).

Career adaptability merupakan konstrak inti dari CCT sebagai gambaran individu yang dituntut untuk mampu menyesuaikan diri dengan tugas -baik yang dapat diprediksikan maupun tidak dapat diprediksikan- sebagai dampak dari perubahan (Savickas, 1997). Career adapatability didefinisikan sebagai konstrak psikososial yang menunjukkan sumber penyesuaian individu terhadap tugastugas, transisi, dan tekanan pekerjaan- baik besar maupun kecil- sebagai bagian dari integrasi sosialnya. Terdapat 4 sumber psikososial dari career adaptability yaitu concern, control, curiosity, dan confidence atau disebut sebagai 4C's (Savickas \& Porfeli, 2012).

Concern terkait dengan bagaimana cara pandang individu terhadap masa mendatang serta bagaimana dirinya mempersiapkan diri untuk masa mendatang tersebut. Seseorang dengan concern yang baik memandang masa depannya dengan optimis dan harapan positif (Savickas, dkk, 2009). Control membantu individu untuk bertanggung jawab berperan membentuk dirinya dan lingkungannya untuk memenuhi kebutuhan masa mendatang melalui disiplin diri, usaha, dan kegigihan. Control menggambarkan kemampuan regulasi diri dari 
individu tersebut (Savickas, dkk, 2009). Curiosity menggambarkan usaha aktif individu untuk memikirkan dirinya di berbagai situasi dan peran. Curiosity juga menunjukkan keaktifan individu untuk melakukan eksplorasi pengalaman serta melakukan pencarian informasi. (Savickas \& Porfeli, 2012). Sedangkan Confidence terkait dengan keyakinan diri individu dalam meraih aspirasinya dan impiannya di masa mendatang. Individu dengan confidence yang baik meyakini bahwa dirinya mampu membuat pilihan serta mencapai apa yang menjadi tujuannya (Johnston, 2018).

Dalam berbagai hasil penelitian terdahulu career adaptability dapat memprediksikan kesuksesan karir individu misalnya terkait dengan kepuasan kerja dan pendapatan tahunan pekerja (Haibo, Xiaoyu, Xiaoming, \& Zhijin, 2017), kepuasan hidup secara umum (Hirschi, 2009, Santili, Nota, Ginevra, \& Soresi, 2014) serta berkorelasi negatif dengan stress kerja (Rudolph, Lavigne, \& Zacher, 2017). Selain itu career adaptability juga memprediksikan keuntungan bagi perusahaan atau organisasi karena secara semakin tinggi career adaptability memprediksikan makin rendahnya intensi pekerja tersebut untuk keluar pekerjaan, bahkan karakter tersebut dapat memprediksikan tingkat performansi kerja yang makin meningkat (Haibo, dkk, 2017). Secara khusus bagi para pencari kerja, career adaptability mampu memprediksikan kepuasan pencari kerja pada masa transisi (Hirschi, 2010). Control sebagai salah satu sumber psikososial dalam career adapatability berkaitan dengan kemampuan calon pekerja untuk mengantisipasi kesulitan saat sedang mencari pekerjaan (Monteiro \& Almeida, 2015).

Sebagai suatu perspektif yang terbilang baru, career adaptability telah berkembang pesat serta banyak menarik perhatian para ahli di bidang konseling dan pengembangan karier untuk diteliti (lihat Savickas \& Porfeli, 2012, Johnston, 2018). Beberapa penelitian di Indonesia terkait dengan konseling serta pengembangan karier juga telah menggunakan konstrak ini (Muslihati, 2017, Jannah \& Saleh, 2017, Khusna \& Indiati, 2018). Namun demikian konstrak ini belum banyak digunakan untuk mengidentifikasikan employability pada kelompok penyandang disabilitas (lihat Santili, dkk, 2014). 


\section{Metode}

Penelitian ini menggunakan pendekatan penelitian kuantitatif dengan menyebarkan survey secara online. Responden penelitian direkrut menggunakan teknik snow-ball dengan menyebarkan link online survey melalui berbagai kanalkanal online. Khusus untuk kelompok pemuda penyandang disabilitas, penyebaran link survey dibantu oleh beberapa organisasi penyandang disabilitas (OPD) di Jawa Timur.

Pertimbangan penggunaan online survey adalah karena fungsi aksesibilitas yang memungkinkan responden untuk mengisi survey secara mandiri, khususnya bagi disabilitas netra. Adapun survey dibuat menggunakan platform surveymonkey.

Keikutsertaan responden dalam penelitian ini bersifat partisipatif dan tanpa paksaan. Data yang diberikan bersifat anonim (tanpa identitas nama), namun peneliti mendapatkan akses untuk informasi pribadi lainnya misal usia, jenis kelamin, e-mail atau nomor telephone. Platform surveymonkey juga memungkinkan peneliti mendapatkan IP address responden dan mengeliminir kemungkinan reseponden memberikan respon ganda. Sebagai imbalan atas partisipasinya, responden mendapatkan hadiah berupa voucher pulsa.

Tabel 1. Data demografis responden penelitian

\begin{tabular}{lll}
\hline & Penyandang Disabilitas & Non Disabilitas \\
\hline Jenis Kelamin & & \\
Laki-laki & 55 orang & 48 orang \\
Perempuan & 33 orang & 86 orang \\
Usia & & \\
Range & $18-35$ tahun & $20-35$ tahun \\
Rata & 25,76 tahun & 23,49 tahun \\
SD & 4,887 & 3,470 \\
Pendidikan Terakhir & & \\
Tidak bersekolah & 6 orang & 0 orang \\
SD & 0 orang & 0 orang \\
SMP & 5 orang & 0 orang \\
SMA & 53 orang & 55 orang \\
Diploma & 6 orang & 12 orang \\
S1 & 15 orang & 61 orang \\
S2 & 3 orang & 6 orang \\
\hline
\end{tabular}


Dari survey tersebut didapatkan 231 total data dan hanya 222 data yang dapat diolah lebih lanjut atau memiliki return rate sebesar 96,1\%. Lebih rinci lagi responden terdiri dari 88 orang penyandang disabilitas dan 134 orang non disabilitas. Prosentase partisipan dengan disabilitas sebesar 39\% dari banyaknya partisipan non disabilitas. Sebagai kelompok minoritas maka terdapat tantangan dalam mendapatkan jumlah penyandang disabilitas yang benar-benar setara dengan kelompok non disabilitas. Menurut hasil survey Indonesia Family Life Survey (IFLS) tahun 2010 dan Survei Sosial Ekonomi Nasional (Susenas) tahun 2016, jumlah penyandang disabilitas berkisar antara 10-14\% dari total penduduk Indonesia. Penyandang disabilitas berasal dari kelompok yang bervariasi yaitu 24 orang tunanetra, 19 orang tuli, 36 orang tunadaksa, 4 orang cerebral palsy, dan 5 orang dengan disabilitas lain, seperti autisme dan ADHD. Data demografis ditunjukkan di tabel 1.

Dalam survey tersebut terdapat beberapa instrumen penelitian termasuk skala Career Adapt-Ability Scale (CAAS) versi Indonesia. CAAS sendiri adalah instrumen yang dibangun oleh Porfeli \& Savickas (2012) yang terdiri dari 4 dimensi yaitu concern, control, curiosity, dan confidence. Pada versi aslinya, masing-masing dimensi diwakili oleh 6 butir pernyataan sehingga total keseluruhan terdiri dari 24 butir pernyataan.

Berdasarkan uji coba yang dilakukan peneliti sebelumnya, dipilih butir-butir yang memiliki daya diskriminasi yang baik. Didapatkan 6 butir pernyataan mewakili dimensi concern (contohnya: "Saya memikirkan seperti apa masa depan saya nanti"), 4 butir pernyataan mewakili dimensi control (contohnya: "Saya berpegang teguh pada keyakinan saya", 6 butir pernyataan mewakili dimensi curiosity (contohnya: "Saya mencari kesempatan untuk berkembang sebagai individual"), dan 6 butir pernyataan mewakili dimensi confidence (contohnya: "Saya bekerja hingga batas kemampuan saya"). Total pernyataan untuk CAAS versi adaptasi ini memiliki 22 butir pernyataan. Instrumen ini memiliki reliabilitas internal yang baik, ditunjukkan dengan nilai alpha cronbach sebesar 0,906. Begitu pula alpha cronbach untuk masing-masing dimensinya yaitu Concern = 0,827; Control $=0,661$, Curiosity $=0,792$, Confidence $=0,810$. Dalam 
pengerjaannya, partisipan penelitian diminta untuk memilih salah satu respon yang disusun dalam 5-poin skala Likert, bergerak dari 1(sangat tidak setuju) sampai 5 (sangat setuju). Semakin tinggi rata-rata total skor dari skala ini menunjukkan career adaptability yang semakin baik.

Untuk menguji hipotesis dalam penelitian ini, peneliti menggunakan teknik analisis independent sample t-test. Untuk memperdalam hasil penelitian maka masing-masing dimensi career adaptability dianalisis juga menggunakan teknik analisis yang sama. Seluruh analisis dilakukan dengan bantuan perangkat lunak SPSS versi 23.0

\section{Hasil dan Pembahasan}

\section{Hasil}

Sebelum melakukan uji hipotesis, peneliti melakukan uji pendahuluan untuk memeriksa apakah terdapat variabel-variabel lain yang mungkin mempengaruhi hasil uji hipotesis nantinya. Uji pendahuluan tersebut menguji apakah terdapat pengaruh usia dan jenis kelamin terhadap career adaptability. Uji korelasi Pearson's product moment digunakan untuk menguji hubungan antara usia dengan career adaptability dan tidak ditemukan hubungan yang signifikan di antara keduanya $(r=0,007, p=0,917)$. Dengan menggunakan independent sampe t-test tidak ditemukan hubungan jenis kelamin dengan career adaptability $(\mathrm{t}=0,715, p=0,476)$. Oleh karena usia dan jenis kelamin diasumsikan tidak memiliki peran terhadap variasi career adaptability.

Berdasarkan uji hipotesis dengan menggunakan independent sample t-test didapatkan $\mathrm{t}=3,138(p=0,002)$. Dengan itu dapat disimpulkan terdapat perbedaan career adaptability yang signifikan antara kelompok penyandang disabilitas $(\mathrm{M}=4,308, \mathrm{SD}=0,434)$ dan non disabilitas $(\mathrm{M}=4,128, \mathrm{SD}=0,404)$. Dapat dilihat bahwa secara umum nilai career adaptability penyandang disabilitas lebih tinggi daripada kelompok non disabilitas.

Untuk mempertajam analisis data, peneliti melakukan analisis tambahan untuk menguji perbedaan masing-masing dimensi dari career adaptability, yaitu pada dimensi concern, control, curiosity, dan confidence. Seluruh uji menggunakan teknik analisis independent sample t-test. Dari hasil analisis 
terdapat 2 dimensi yang menunjukkan perbedaan signifikan antara kelompok penyandang disabilitas dan non disabilitas, yaitu pada dimensi control $(\mathrm{t}=3,107$, $p=0.002)$, dan confidence $(\mathrm{t}=3,681, p<0,001)$. Sedangkan tidak ditemukan perbedaan signifikan antara kelopok penyandang disabilitas dan non disabilitas pada dimensi concern $(\mathrm{t}=1,899, p=0,059)$ dan dimensi curiosity $(\mathrm{t}=1,766$, $p=0,079)$.

Tabel 2. Hasil uji perbedaan antara kelompok penyandang disabilitas dan non disabilitas

\begin{tabular}{llll}
\hline Dimensi & \multicolumn{2}{c}{ Mean (SD) } & Hasil uji t \\
& Penyandang disabilitas & Non disabilitas & \\
\hline $\begin{array}{l}\text { Career } \\
\text { adaptability }\end{array}$ & $4,308(0,434)$ & $4,128(0,404)$ & $\mathrm{t}=3,138 ; p=0,002^{*}$ \\
CAAS-Concern & $4,409(0,494)$ & $4,281(4,889)$ & $\mathrm{t}=1,899 ; p=0,059$ \\
CAAS-Control & $4,511(0,473)$ & $4,306(0,487)$ & $\mathrm{t}=3,107 ; p=0,002^{*}$ \\
CAAS-Curiosity & $4,238(0,519)$ & $4,113(0,516)$ & $\mathrm{t}=1,766 ; p=0,079$ \\
CAAS- & $4,142(0,552)$ & $3,874(0,514)$ & $\mathrm{t}=3,681 ; p<0,001^{*}$ \\
Confidence & & &
\end{tabular}

Ket. *) menunjukkan perbedaan yang signifikan

\section{Pembahasan}

Dari hasil analisis, secara umum terdapat perbedaan career adaptability antara kelompok penyandang disabilitas dan non disabilitas. Dari analisis keempat dimensinya, terdapat 2 dimensi yang menunjukkan perbedaan signifikan yaitu pada dimensi control dan confidence. Sedangkan tidak ditemui perbedaan signifikan dari 2 dimensi lainnya, yaitu concern dan curiosity. Dari dimensidimensi yang memiliki perbedaan yang signifikan nampak bahwa tingkatan dari kelompok penyandang disabilitas lebih tinggi daripada kelompok non disabilitas.

Secara umum dapat disimpulkan bahwa kelompok disabilitas lebih adaptif dan fleksibel dibandingkan dengan kelompok non disabilitas dalam menghadapi tantangan kerja. Pengalaman hidup yang penuh tantangan mendorong dan melatih penyandang disabilitas untuk terbiasa berlaku fleksibel dan adaptif. Ini berpengaruh juga dengan cara menghadapi tantangan kerja yang membuat penyandang disabilitas memiliki modalitas yang lebih fleksibel dan lenting dibandingkan kelompok non disabilitas.

Secara khusus penyandang disabilitas, perbedaan yang tampak adalah pada dimensi control penyandang disabilitas dalam menghadapi tantangan kerja. Dimensi ini menjelaskan bahwa usaha yang dikerahkan oleh penyandang 
disabilitas dalam menghadapi tuntutan dan tantangan kerja lebih besar dibandingkan usaha serta kegigihan kelompok non disabilitas. Penyandang disabilitas juga cenderung memiliki kedisiplinan diri dan tanggung jawab yang lebih tinggi dibandingkan kelompok non disabilitas dalam konteks karir. Hal ini bisa jadi terkait dengan masih minimnya akses lapangan kerja dan akomodasi bagi para penyandang disabilitas, sehingga untuk memperoleh kerja maka penyandang disabilitas mutlak harus menunjukkan kegigihannya.

Ditinjau dari dimensi confidence, penyandang disabilitas memiliki kecenderungan lebih unggul dibanding non disabilitas. Hal ini terkait dengan keyakinan individu tentang kapasitasnya untuk menyelesaikan tantangantantangan kerja. Optimisme penyandang disabilitas relatif lebih tinggi dibandingkan kelompok lainnya. Dimensi ini diasumsikan merupakan sumber motivasi sehingga pekerja lebih terlibat dalam pekerjaan serta meningkatkan kompetensinya.

Temuan ini jelas bertolak belakang dengan stigma dan pandangan umum kebanyakan bahwa penyandang disabilitas dianggap sebagai tenaga kerja yang kurang prospektif dan kurang menguntungkan dibandingkan tenaga kerja non disabilitas. Tenaga kerja disabilitas dipandang sebagai kelompok yang tidak memiliki wawasan dan ketrampilan kerja yang rendah. Banyak bursa-bursa kerja yang memberikan syarat minimal jenjang pendidikan dalam proses rekrutmen karyawannya. Terkait dengan hal tersebut, para penyandang disabilitas kurang memiliki kesempatan yang setara.

Fakta bahwa $45,74 \%$ penyandang disabilitas belum pernah atau tidak pernah menempuh pendidikan formal sedangkan hanya 12,69\% non disabilitas yang tidak menempuh pendidikan formal menggambarkan kesenjangan tingkatan pendidikan di antara dua kelompok ini (ILO, 2017). Dalam paparan data demografis penelitian ini juga didapatkan fakta bahwa masih ada penyandang disabilitas yang tidak menempuh pendidikan formal (lihat tabel 1). Dari fakta tersebut, tidak dapat dipungkiri bahwa penyandang disabilitas memiliki modalitas pengetahuan dan ketrampilan teknis yang lebih rendah dibandingkan pekerja non disabilitas sebagai pengaruh dari rendahnya tingkat pendidikan. Bisa jadi faktor inilah yang membuat 
para penyandang disabilitas kurang dipertimbangkan dan kurang mampu bersaing di pasar kerja yang inklusif.

Di sisi lain pendidikan sebagai modalitas kerja perlu dipandang lebih kritis lagi. Meta analisis yang dilakukan oleh Johnston (2018) menyatakan bahwa karakteristik pendidikan yang dapat mengestimasi kesuksesan kerja bukan semata-mata adalah tingkat pendidikannya tapi juga kedalamannya, misalnya jenis pendidikan ketrampilan tertentu dan training vokasional tertentu. Hal ini sejalan dengan pendapat Fugate, Kinicki, \& Ashforth (2004) bahwa lebih detail lagi, pendidikan tinggi vokasional, sertifikasi, serta pendidikan profesional yang terkait dengan kelayakan kerja individu.

Ditinjau dari paradigma employability yang dicetuskan oleh Fugate dkk (2004) bahwa modalitas ketrampilan dan pengetahuan hanya merupakan salah satu modalitas kelayakan kerja. Terdapat faktor lain yang mempengaruhi kelayakan kerja yaitu identitas karir dan personal adaptability. Pada penelitian yang melibatkan responden pencari kerja didapatkan hasil bahwa tingkat pendidikan bukan merupakan faktor prediktor dari keaktifan mencari kerja. Secara berkebalikan, fleksibilitas dirilah yang menjadi faktor yang lebih signifikan (McArdle, Waters, Briscoe, \& Hall, 2007). Dalam hal ini, jelaslah para penyandang disabilitas memiliki keunggulan karena memiliki karakter yang lebih fleksibel dibandingkan kelompok non disabilitas.

Mengingat keunggulan utama penyandang disabilitas dalam konteks career adaptability menyangkut dimensi control dan conficence, maka kedua hal tersebut hendaknya menjadi perhatian lebih lanjut. Penelitian Hirschi, Herrmann, \& Keller (2015) menunjukkan hubungan antara dimensi control dengan keterlibatan dan tanggung jawab individu untuk merencanakan dan membuat keputusan. Dalam hal ini, dapat diprediksi bahwa penyandang disabilitas memiliki tanggung jawab dan terlibat lebih aktif dalam menentukan karirnya.

Hal ini dapat menjadi angin segar bagi pemangku kebijakan terkait dengan pengembangan inklusivitas lapangan kerja. Dari modalitas instrinsiknya, khususnya career adaptability, kelompok non disabilitas memiliki kapasitas yang lebih potensial dibandingkan non disabilitas. Hal ini perlu ditonjolkan sebagai 
kekuatan penyandang disabilitas. Individu yang memiliki kapasitas career adapaptability diprediksikan akan mendatangkan banyak keuntungan kepada organisasi karena menurunkan resiko untuk mengalami turnover dan lebih mudah memelihara kepuasan kerja (Johnston, 2018).

Sebagai penutup, perlu pula untuk mengkaji keterbatasan dalam penelitian ini sehingga tidak menghasilkan generalisasi yang bias. Dalam penelitian ini, responden penyandang disabilitas didapatkan dari teknik snow-ball yang berasal dari OPD. Oleh karena itu terdapat probabilitas besar bahwa responden penyandang disabilitas dalam penelitian ini adalah aktivitis OPD. Peran sebagai aktivis OPD membuka pengalaman dan jaringan sosial yang lebih beragam dan lebih luas. Di sisi lain, responden non disabilitas tidak didapatkan dari jaringan organisasi-organisasi namun semata mengandalkan jaringan media sosial yang bersifat lebih casual. Oleh karena itu, latar belakang aktivitas organisasi yang mempengaruhi pengalaman dan jaringan sosial mungkin tidak setara dengan kelompok penyandang disabilitas.

Di sisi lain, penelitian ini terbatas pada kelompok penyandang disabilitas di Jawa Timur. Akibat aksesibilitas yang lebih baik di Pulau Jawa mungkin tidak dapat mewakili gambaran penyandang disabilitas di luar Jawa Timur ataupun di luar Pulau Jawa yang lebih komprehensif.

Survey yang dilakukan dengan media online membawa kemudahan bagi penelitian dan mendukung kemandirian untuk aksesibilitas penyandang disabilitas, khususnya disabilitas netra. Namun demikian, bisa jadi penelitian ini hanya mampu merekrut kalangan sosial ekonomi menengah atas yang familiar dengan teknologi informasi serta memiliki akses internet. Fakta bahwa tidak semua masyarakat memiliki kapabilitas tersebut hendaknya menjadi pertimbangan.

\section{Kesimpulan dan Saran}

\section{Kesimpulan}

Career adapatability kelompok penyandang disabilitas relatif lebih tinggi dibandingkan dengan kelompok non disabilitas. Secara khusus, penyandang 
disabilitas juga unggul dalam 2 dimensi career adaptability yaitu control dan confidence. Temuan ini diharapkan dapat mengikis stereotipe negatif terkait dengan kapabilitas dan modalitas kerja penyandang disabilitas yang dipandang lebih rendah dibandingkan kelompok non disabilitas.

\section{Saran}

1. Kedepannya hasil penelitian ini dapat digunakan untuk referensi bagi pembuat keputusan di organisasi maupun lapangan kerja untuk lebih terbuka terhadap tenaga kerja disabilitas dan ikut serta mewujudkan masyarakat yang lebih inklusif, khususnya terkait dengan penyediaan lapangan pekerjaan.

2. Hasil penelitian ini juga dapat digunakan oleh lembaga-lembaga pendidikan dan pelatihan yang berkepentingan dalam mendukung kapasitas penyandang disabilitas dalam meningkatkan kapasitasnya untuk bersaing di lapangan kerja. Dukungan dan program untuk semakin menguatkan kegigihan serta kepercayaan diri penyandang disabilitas dapat dikembangkan sebagai dasar persiapan kerja bagi penyandang disabilitas.

3. Terbuka kesempatan yang lebar untuk mengembangkan penelitian ini, misalnya untuk mengkaji lebih lanjut faktor-faktor yang memperkuat career adaptability penyandang disabilitas.

4. Karena dalam penelitian ini, populasi penyandang disabilitas terbatas pada penyandang disabilitas di Jawa Timur maka penelitian sejenis dapat dilakukan di wilayah lain di Indonesia, khususnya yang memiliki kareteristik berbeda dari karakteristik penyandang disabilitas di Jawa Timur.

\section{DAFTAR PUSTAKA}

Autin, K., Douglass, R., Duffy, R., England, J., \& Allan, B. (2017). Subjective social status, work volition, and career adaptability: A longitudinal study. Journal of Vocational Behavior, 99, 1-10.

Fugate, M., Kinicki, A. J., \& Ashforth, B. E. (2004). Employability: A psychosocial construct, its dimensions, and applications. 65, 14-38.

Haibo, Y., Xiaoyu, G., Xiaoming, Z., \& Zhijin, H. (2017, August). Career adaptability with or without career identity: How career adaptability leads to 
organizational success and individual career success? Journal of Career Assessment, 26(4), 717-731.

Hirschi, A. (2009). Career adaptability development in adolescence: Multiple predictors and effect on sense of power and life satisfaction. Journal of Vocational Behavior, 74(2), 145-155.

Hirschi, A., Herrmann, A., Keller, A.C. (2015). Career adaptivity, adaptability, and adapting: A conceptual and empirical investigation. Journal of Vocational Behavior, 87(1), 1-10

Hirschi, A. (2010). The role of chance events in the school-to-work transition: The influence of demographic, personality and career development variables. Journal of Vocational Behavior, 77(1), 39-49.

ILO. (2017). Laporan akhir - Memetakan penyandang disabilitas (PD) di pasar tenaga kerja indonesia. International Labour Organization . Jakarta: Organisasi Perburuhan Internasional, Kantor Jakarta.

Jannah, U., \& Saleh, A. (2017). The Correlation between sibling relationship and career adaptability among 9th grade students. Universitas Indonesia International Psychology Symposium for Undergraduate Research (pp. 8994). Jakarta: Atlantic Press.

Johnston, C. (2018, February). A systematic review of the career adaptability literature and future outlook. Journal of Career Assessment, 26(1), 3-30.

Kaye, H., Jans, L., \& Jones, E. (2011). Why don't employers hire and retain workers with disabilities? Journal of Occupational Rehabilitation, 21(4), 526-536.

Khusna, U., \& Indiati, W. (2016). Relationship between parental attachment and career adaptability in grade 12 senior high school students. Diversity in Unity: Perspectives from Psychology and Behavioral Sciences. Depok: Taylor \& Francis Group.

Khusna, U., \& Indiati, W. (2018). Relationship between parental attachment and career adaptability in grade 12 senior high school students. The asia-pacific research in social sciences and humanities, (pp. 297-302). Depok: Taylor \& Francis Group.

McArdle, S., Waters, L., Briscoe, J., \& Hall, D. (2007). Employability during unemployment: Adaptability, career identity and human and social capital. Journal of vocational behavior, 71, 247-264. 
Monteiro, S., \& Almeida, L. (2015). The relation of career adaptability to work experience, extracurricular activities, and work transition in Portuguese graduate students. Journal of Vocational Behavior, 91, 106-112.

Muslihati. (2017). A Study of Career Adaptability and Career Planning of Faculty of Education Students of Universitas Negeri Malang. 9th International Conference for Science Educators and Teachers (ICSET) (pp. 301-106). Semarang: Atlantic Press.

Rudolph, C., Lavigne, K., \& Zacher, H. (2017, February). Career adaptabil- ity: A meta-analysis of relationships with measures of adaptivity, adapting responses, and adaptation results. Journal of Vocational Behavior , 98, 1734.

Santili, S., Nota, L., Ginevra, M., \& Soresi, S. (2014). Career adaptability, hope and life satisfaction in workers with intellectual disability. Journal of Vocational Behavior, 85(1), 67-74.

Savickas, M. (1997, March). Career adaptability: An integrative construct for lifespan, life-space theory. The career development quarterly, 45, 247-259.

Savickas, M. (2005). The theory and practice of career construction. In R. Lent, \& S. Brown, Career development and counseling: Putting theory and research to work (pp. 42-70). Hoboken, New Jersey: John Wiley \& Sons.

Savickas, M., \& Porfeli, E. (2012). Career Adapt-Abilities Scale: Construction, reliability, and measurement equivalence across 13 countries. Journal of Vocational Behavior, 80, 661-673.

Savickas, M., Nota, L., Rossier, J., Dauwalder, J.-P., Duarte, M., Guichard, J., . . . van Vianen, A. (2009). Life designing: A paradigm for career construction in the 21st century. Journal of Vocational Behavior, 75, 239-250. 